\title{
ANALISIS DAMPAK PERISTIWA PENGUMUMAN PERINGKAT SUKUK TERHADAP REAKSI PASAR PADA PERUSAHAAN YANG TERDAFTAR DI JAKARTA ISLAMIC INDEX (JII)
}

\author{
Fadila Imran*1, Meutia Fitri ${ }^{* 2}$ \\ ${ }^{1,2}$ Program Studi Akuntansi Fakultas Ekonomi dan Bisnis Universitas Syiah Kuala \\ e-mail: fadilaimran@ @ahoo.com ${ }^{* 1}$, meutia.fitri@ unsyiah.ac.id ${ }^{* 2}$
}

\begin{abstract}
The purpose of this research is to analyze the impact of sukuk rating announcement event upon market reaction in company which registered at Jakarta Islamic Index (JII) from 2011 until 2015 using average abnormal return during five days before and after event. The type of data used in this research is secondary data which obtained from financial statements publishing by capital market reference center that existed in Indonesia Stock Exchange. The sample used in this research is study case with the total of the population is 7 companies. Method used in this research is purposive sampling which yielded 5 companies sample for sukuk rating announcement event. Meanwhile, the examination of hypothesis used is event study method. The result of this research illustrate that sukuk rating announcement event did not give an impact upon market reaction. However, in case of considering each variable, there is a difference between before and after the occurrence of sukuk rating announcement event.
\end{abstract}

Keywords: Sukuk Rating Announcement, Market Reaction, and Abnormal Return.

\section{Pendahuluan}

Pasar modal merupakan salah satu elemen penting bagi suatu negara dan menjadi tolok ukur kemajuan perekonomian negara, karena pasar modal memuat berbagai peristiwa yang memiliki kandungan informasi bagi investor. Salah satu ciri negara industri maju maupun negara industri baru adalah adanya pasar modal yang tumbuh dan berkembang dengan baik.

Informasi merupakan suatu kebutuhan utama para investor di pasar modal. Relevan atau tidaknya sebuah informasi akan berdampak pada penilaian investor mengenai prospek kinerja emiten sehingga investor memiliki gambaran tentang risiko dan expected return atas dana yang telah atau akan diinvestasikan. Dalam pasar modal yang efisien, pasar akan bereaksi secara cepat terhadap semua informasi yang relevan. Pada umumnya hal ini ditunjukkan oleh perubahan harga saham yang melebihi kondisi normal sehingga menimbulkan abnormal return (Primadani, 2013).

Segala peristiwa yang terjadi dalam lingkungan perusahaan akan berdampak pada perubahan harga saham dan dapat menghasilkan abnormal return, misalnya peristiwa pengumuman laba, pengumuman kebijakan dividen, pengumuman akuisisi atau merger, dan sebagainya. Selain itu, peristiwa yang berkaitan dengan lingkungan ekonomi makro seperti inflasi, perubahan suku bunga tabungan dan deposito, kurs valuta asing, serta berbagai regulasi dan deregulasi ekonomi yang dikeluarkan pemerintah turut berpengaruh pada fluktuasi harga dan volume perdagangan pada pasar modal yang efisien (Manullang, 2004; Suryawijaya \& Setiawan, 1998).

Informasi mengenai suatu peristiwa yang terjadi di pasar modal akan direaksi oleh investor secara metodologis yang disebut sebagai event study. Suryawijaya dan Setiawan (1998) menyatakan bahwa event study merupakan suatu pengamatan mengenai pergerakan harga saham di pasar modal untuk mengetahui apakah ada abnormal return yang diperoleh pemegang saham akibat adanya suatu peristiwa tertentu. Pengamatan itu biasanya dilakukan dengan melihat perilaku return saham di sekitar kejadian yang diamati. Sedangkan Jogiyanto (2010:318) menyebutkan bahwa event study merupakan studi yang mempelajari reaksi pasar terhadap suatu peristiwa yang informasinya dipublikasikan sebagai suatu pengumuman. Beberapa event study yang telah dilakukan untuk menganalisis reaksi pasar modal Indonesia terhadap peristiwa- 
peristiwa ekonomi dalam negeri berhasil membuktikan bahwa peristiwa-peristiwa tersebut memiliki kandungan informasi yang relevan bagi para pelaku pasar modal sehingga pasar dapat bereaksi (Manullang, 2004).

Signalling theory menekankan pentingnya informasi yang dikeluarkan oleh perusahaan terhadap keputusan investasi pihak di luar perusahaan. Informasi merupakan unsur yang sangat penting bagi investor dan pelaku bisnis karena informasi pada hakikatnya menyajikan keterangan, catatan atau gambaran baik untuk keadaan masa lalu, saat ini maupun keadaan masa yang akan datang bagi kelangsungan hidup suatu perusahaan. Investor dalam mengambil keputusan untuk berinvestasi terkadang mempertimbangkan informasi yang diberikan oleh manajemen perusahaan. Harga saham bergerak secara acak, berarti fluktuasi harga saham tergantung pada informasi baru (new information) yang diterima, tetapi informasi tersebut tidak diketahui kapan akan diterimanya. Apakah informasi tersebut bersifat kabar buruk (bad news) ataukah kabar baik (good news) juga tidak diketahui (Samsul, 2006:269).

Informasi yang dimiliki oleh investor lebih sedikit dibandingkan dengan informasi yang dimiliki oleh pihak manejemen, hal ini disebut sebagai informasi yang tidak simetris (asymetric information). Oleh karena itu, dalam pengambilan keputusan investor sering mendasarkan pada sinyal yang diberikan oleh perusahaan, salah satunya adalah pengumuman peringkat sukuk (obligasi syariah). Pengumuman peringkat sukuk ini dianggap dapat mempengaruhi keadaan pasar modal.

Pengumuman peringkat sukuk merupakan suatu peristiwa dimana dikeluarkannya peringkat oleh lembaga yang secara khusus bertugas memberikan peringkat atas semua obligasi yang diterbitkan perusahaan. Peringkat tersebut merupakan penilaian yang menyatakan mutu dari sebuah obligasi yang mencerminkan kemungkinan gagal bayar yang disebut dengan risiko kredit (Bringham dan Houston, 2006:373). Di luar negeri lembaga pemeringkat yang menjadi rujukan adalah Moody's Investor Service dan Standard\&Poor's, lembaga tersebut melakukan evaluasi dan analisis kemungkinan pembayaran surat hutang (debt) yang macet. Sementara lembaga pemeringkat di Indonesia sendiri yang menjadi market leader dalam pemberian rating yaitu PT Pemeringkat
Efek Indonesia (PEFINDO), lembaga ini bertugas menjalankan fungsi peringkat efek-efek yang ada di pasar modal Indonesia termasuk obligasi dan sukuk (Rahardjo, 2003).

Darmadji dan Fakhruddin (2006) menyatakan bahwa semua obligasi yang diterbitkan wajib diberi peringkat (rating) sedemikian agar investor dapat mengukur atau memperkirakan seberapa besar risiko yang akan dihadapi dengan membeli obligasi tertentu. Rating dari sebuah obligasi yang diterbitkan perusahaan menentukan perusahaan tersebut bisa mendapatkan pendanaan atau tidak pada saat menerbitkan obligasi. Rating yang dimaksud adalah penilaian yang terstandarisasi atas kemampuan suatu perusahaan dalam membayar hutang-hutangnya. Karena terstandarisasi, rating sebuah perusahaan dapat dibandingkan dengan perusahaan yang lain, sehingga dapat dibedakan siapa yang mempunyai kemampuan yang lebih baik.

Di pasar modal Indonesia, pasca dikeluarkannya Undang-Undang Nomor 19 Tahun 2008 Tentang Surat Berharga Syariah Negara (SBSN), maka obligasi syariah semakin dikenal. Hal ini dikarenakan tidak hanya pemerintah yang mengeluarkan produk tersebut sebagai salah satu alternatif pembiayaan negara, tetapi perusahaan nasional atau korporasi pun juga ikut menerbitkan obligasi syariah untuk pembiayaan perusahaan. Fenomena ini mengundang perhatian para investor di pasar modal. Menurut Ahmad dan Zakaria (2010), ketika seorang investor ingin menanamkan modalnya pada sebuah obligasi syariah, maka investor memerlukan informasi mengenai obligasi syariah serta perusahaan yang menerbitkan obligasi syariah tersebut, terutama mengenai kemampuan perusahaan dalam memenuhi kewajibannya.

Setiap investor di pasar modal yang akan berinvestasi pada suatu obligasi syariah pasti mengharapkan return (tingkat pengembalian) atas investasi yang dilakukannya tersebut. Ang (1997) menjelaskan, tanpa adanya keuntungan yang dapat dinikmati tentunya investor tidak akan mau berinvestasi, begitu pula hal nya dengan investasi yang dilakukan pada obligasi syariah.

Sukuk (obligasi syariah) merupakan surat hutang jangka panjang, sehingga untuk menghindari kemungkinan mendapatkan kerugian investasi di masa mendatang maka penting sekali bagi seorang investor untuk memilih investasi mana yang benar-benar aman. 
Dalam hal ini, salah satu indikator yang dapat dijadikan acuan untuk menggambarkan informasi mengenai suatu obligasi adalah peringkat. Peringkat (rating) sebuah obligasi dapat dijadikan indikator yang digunakan oleh investor untuk memperkirakan kemampuan perusahaan dan memperkecil risiko bisnis. Semakin tinggi rating yang diberikan oleh lembaga pemeringkat atas sebuah obligasi maka semakin baik pula kualitas perusahaannya. Namun, peringkat obligasi ini hanya menjadi acuan bagi investor dalam menilai suatu obligasi, tetapi tidak menjamin ketika suatu obligasi dengan peringkat AAA akan berjalan lancar.

Informasi pengumuman peringkat sukuk akan menimbulkan reaksi dari pelaku pasar modal yang dapat mempengaruhi harga saham suatu perusahaan. Pelaku pasar modal dapat bereaksi pada waktu sebelum, saat, dan setelah pengumuman dipublikasikan. Reaksi ini dapat dilihat melalui return saham perusahaan terkait. Apabila investor memanfaatkan informasi dari pengumuman peringkat sukuk dalam kegiatannya, maka publikasi tersebut akan berpotensi menyebabkan perubahan return saham dibandingkan hari-hari di luar pengumuman. Kenaikan sukuk rating (upgrade) akan menarik perhatian para investor, karena upgrade ini mengindikasikan terjadinya kenaikan tingkat return suatu perusahaan dan penurunan tingkat risiko, sehingga akan lebih banyak investor yang tertarik untuk menanamkan modalnya di perusahaan tersebut. Penurunan sukuk rating (downgrade) merupakan kebalikan dari upgrade dimana tingkat return perusahaan menurun dan tingkat risiko meningkat. Hal ini dapat mengakibatkan banyak investor yang menarik investasi, karena mereka tidak ingin menanggung kerugian besar dalam berinvestasi pada suatu perusahaan.

Salah satu penelitian yang dilakukan untuk melihat pengaruh pengumuman peringkat sukuk terhadap reaksi pasar pernah dilakukan oleh Srianingsih dan Khoiruddin (2015). Penelitian ini menunjukkan bahwa tidak ditemukannya perbedaan return yang signifikan antara sebelum dan sesudah pengumuman peringkat sukuk.

Penelitian ini dilakukan pada perusahaan yang terdaftar di Jakarta Islamic Index (JII). Penelitianpenelitian terdahulu banyak dilakukan dengan menggunakan populasi dan sampel pada perusahaan yang terdaftar di Bursa Efek Indonesia (BEI), sementara penelitian yang menganalisis pada objek Jakarta Islamic Index (JII) relatif masih sangat sedikit. Sehubungan dengan hal ini, maka sangat perlu untuk dilakukannya penelitian lebih lanjut pada objek tersebut.

\section{Kajian Teoritis dan Pengembangan Hipotesis Reaksi Pasar}

Reaksi pasar akibat terjadinya suatu peristiwa ditunjukkan dengan adanya fluktuasi harga saham dari sekuritas yang bersangkutan. Sebagaimana disebutkan dalam Jogiyanto (2003) bahwa reaksi pasar tersebut dapat diukur dengan menggunakan return sebagai nilai perubahan harga atau dengan mengunakan return tidak normal (abnormal return). Return saham ini diasumsikan akan mengalami perubahan ketika ada informasi baru yang diserap oleh pasar. Jika digunakan abnormal return, maka dapat dikatakan bahwa suatu pengumuman yang mempunyai kandungan informasi akan memberikan abnormal return kepada pasar. Sebaliknya, apabila pengumuman tersebut tidak mengandung informasi maka tidak akan memberikan abnormal return kepada pasar.

Abnormal return menurut Samsul (2006:275) yaitu selisih antara tingkat keuntungan yang sebenarnya (actual return) dengan tingkat keuntungan yang diharapkan (expected return). Abnormal return atau excess return ini merupakan selisih dari return yang sesungguhnya terjadi terhadap return normal. Return normal yang dimaksud adalah return ekspektasi (return yang diharapkan oleh investor) dengan mempertimbangkan tingkat risikonya.

\section{Pengumuman Peringkat Sukuk}

Pengumuman peringkat sukuk merupakan suatu peristiwa dimana dikeluarkannya peringkat oleh lembaga yang secara khusus bertugas memberikan peringkat atas semua obligasi yang diterbitkan perusahaan. Peringkat tersebut merupakan penilaian yang menyatakan mutu dari sebuah obligasi dan mencerminkan kemungkinan gagal bayar (Bringham dan Houston, 2006:373) yang disebut dengan risiko kredit. Peringkat sukuk merupakan skala risiko dari semua sukuk yang diperdagangkan dan menunjukkan seberapa aman sukuk tersebut, keamanan ini ditunjukkan oleh kemampuan emiten dalam membayar bagi hasil/marjin serta pelunasan pokok pinjaman. 
Menurut Widoatmodjo (2012) lembaga pemeringkat kredit/obligasi atau Credit Rating Agency (CRA) adalah lembaga yang memberikan jasa penilaian terhadap obligasi yang beredar. Penilaian ini ditentukan melalui kode tertentu, sesuai dengan tradisi yang dimiliki masing-masing lembaga tersebut. Dua lembaga yang mempunyai reputasi internasional yang sangat dipercaya dalam memberikan penilaian adalah Moody's Investor Service dan Standard\&Poor's, sedangkan lembaga pemeringkat di Indonesia adalah PT PEFINDO, Kasnic Rating Indonesia, Fitch Ratings, dan Fitch Ratings Indonesia. Hasil peringkat yang telah dibuat oleh lembaga tersebut akan diinformasikan kepada masyarakat sebagai sebuah pengumuman.

Nurjanah (2016) telah melakukan penelitian mengenai pengaruh pengumuman peringkat obligasi dan peringkat sukuk perusahaan terhadap abnormal return di Indonesia. Hasil dari penelitian menunjukkan bahwa secara umum tidak terdapat pengaruh pengumuman peringkat obligasi terhadap abnormal return, abnormal return hanya terjadi pada hari kedua sesudah pengumuman. Sedangkan untuk pengumuman peringkat sukuk tidak terdapat abnormal return baik sebelum, saat, dan setelah pengumuman. Abnormal return tersebut tidak menunjukkan perbedaan yang signifikan antara return sebelum dan setelah pengumuman peringkat obligasi maupun peringkat sukuk.

Penelitian yang dilakukan oleh Archana dan Jayanna (2015) untuk mengetahui pengaruh perubahan rating terhadap harga saham di India menunjukkan bahwa pengumuman kenaikan peringkat (rating upgrade) akan memberikan pengaruh negatif tidak signifikan terhadap rata-rata abnormal return dan pengumuman penurunan peringkat (rating downgrade) akan memberikan pengaruh positif tidak signifikan terhadap rata-rata abnormal return.

$\mathrm{H}_{\mathrm{a}}$ : Pasar bereaksi terhadap peristiwa pengumuman peringkat sukuk pada perusahaan yang pernah terdaftar di Jakarta Islamic Index (JII) dari tahun 2011-2015

\section{Metode Penelitian}

\section{Desain Penelitian}

Penelitian ini bertujuan untuk melihat dampak dari peristiwa pengumuman peringkat sukuk terhadap reaksi pasar dengan mengamati pergerakan harga saham di pasar modal melalui metode penelitian deskriptif kuantitatif. Penelitian deskriptif merupakan penelitian yang bertujuan untuk mempelajari serta menjelaskan karakteristik variabel yang akan diteliti berdasarkan situasi yang diminati. Penelitian ini merupakan penelitian studi peristiwa (event study). Menurut Jogiyanto (2010:318), studi peristiwa adalah jenis studi yang mempelajari reaksi pasar terhadap suatu peristiwa yang informasinya dipublikasikan sebagai suatu pengumuman. Dalam penelitian ini tingkat intervensi yang digunakan oleh peneliti adalah minimal. Situasi studi yang digunakan dalam penelitian ini adalah situasi non contrived (tidak diatur). Unit analisis dalam penelitian ini yaitu tingkat organisasi yang mana penelitian dilakukan pada perusahaan yang pernah terdaftar di Jakarta Islamic Index (JII) dari tahun 2011-2015. Data yang dikumpulkan dalam penelitian ini adalah harga saham pada 5 hari sebelum terjadinya peristiwa, hari terjadinya peristiwa, dan 5 hari setelah terjadinya peristiwa. Horizon waktu yang digunakan dalam penelitian ini adalah pooled/panel data. Pooled/panel data merupakan kombinasi antara cross sectional dan time series.

\section{Populasi dan Sampel Penelitian}

Populasi pada penelitian ini adalah seluruh perusahaan yang pernah terdaftar di Jakarta Islamic Index (JII) dan mengeluarkan sukuk dari tahun 20112015. Metode pengambilan sampel pada penelitian menggunakan metode purposive sampling, yaitu teknik yang digunakan untuk pengambilan sampel dengan kriteria tertentu sesuai dengan kebutuhan peneliti (Suharyadi dan Purwanto, 2004:323). Sampel pada penelitian ini ditentukan berdasarkan kriteria sebagai berikut.

\section{Sampel Peristiwa Pengumuman Peringkat Sukuk}

\begin{tabular}{|c|l|c|}
\hline No. & \multicolumn{1}{|c|}{ Kriteria Sampel } & $\begin{array}{c}\text { Jumlah } \\
\text { Perusahaan }\end{array}$ \\
\hline 1. & $\begin{array}{l}\text { Perusahaan yang pernah } \\
\text { terdaftar di Jakarta Islamic } \\
\text { Index (JII) dan } \\
\text { mengeluarkan sukuk dari } \\
\text { tahun 2011-2015 }\end{array}$ & 7 \\
\hline 2. & $\begin{array}{l}\text { Perusahaan yang peringkat } \\
\text { sukuknya tidak di rating }\end{array}$ & $(2)$ \\
\hline
\end{tabular}




\begin{tabular}{|c|c|c|}
\hline No. & Kriteria Sampel & $\begin{array}{c}\text { Jumlah } \\
\text { Perusahaan }\end{array}$ \\
\hline $\begin{array}{l}\text { oleh PT PEFINDO dari } \\
\text { tahun 2011-2015 }\end{array}$ & \\
\hline \multicolumn{2}{|l|}{ Jumlah sampel } & 5 \\
\hline
\end{tabular}

Sumber: Data Diolah (2017)

\section{Sumber dan Teknik Pengumpulan Data}

Sumber data yang digunakan dalam penelitian ini adalah data sekunder, yaitu yang mengacu pada informasi yang dikumpulkan dari sumber yang telah ada. Bentuk penelitian ini adalah penelitian studi peristiwa (event study). Adapun data yang digunakan yaitu:

1. Harga saham. Harga saham yang digunakan adalah harga penutupan (closing price) dari perusahaan yang pernah terdaftar di Jakarta Islamic Index (JII) dari tahun 2011-2015 untuk menghitung return, expected return, dan abnormal return.

2. IHSG (Indeks Harga Saham Gabungan). Harga penutupan IHSG yang digunakan adalah data harian dari sebelum pengumuman sampai setelah pengumuman peringkat sukuk.

3. Data peringkat sukuk dari tahun 2011-2015 yang didapatkan dari PT PEFINDO.

Jenis data yang digunakan dalam penelitian ini adalah data sekunder. Data sekunder ini biasanya telah dikumpulkan oleh lembaga pengumpul data lalu dipublikasikan kepada masyarakat. Metode pengumpulan data penelitian dengan cara dokumenter. Data dalam penelitian ini data bersumber dari:

1. Situs www.syariahsaham.com

2. Situs www.ojk.go.id

3. Situs www.pefindo.com

4. Situs www.finance.yahoo.com

5. Situs www.sahamok.com

\section{Operasionalisasi Variabel}

\section{Reaksi Pasar}

Reaksi pasar dapat diukur dengan menggunakan return sebagai nilai perubahan harga atau dengan mengunakan return tidak normal (abnormal return). Abnormal return dapat diketahui dengan cara return yang sesungguhnya (actual return) dikurangi return yang diharapkan (expected return), dapat dirumuskan:

$$
\mathrm{RTN}_{\mathrm{i}, \mathrm{t}}=\mathrm{R}_{\mathrm{i}, \mathrm{t}}-\mathrm{E}\left(\mathrm{R}_{\mathrm{i}, \mathrm{t}}\right)
$$

\section{Keterangan:}

$\mathrm{RTN}_{\mathrm{i}, \mathrm{t}}=$ return tidak normal sekuritas i pada hari ke-t

$\mathrm{R}_{\mathrm{i}, \mathrm{t}} \quad=$ actual return sekuritas i pada hari ke-t

$\mathrm{E}\left(\mathrm{R}_{\mathrm{i}, \mathrm{t}}\right)=$ expected return sekuritas i pada hari ke-t

\section{Pengumuman Peringkat Sukuk}

Pengumuman peringkat sukuk merupakan suatu peristiwa yang terjadi di pasar modal tempat diumumkannya peringkat sukuk perusahaan oleh lembaga yang secara khusus bertugas memberikan peringkat. Pengumuman peringkat sukuk dilihat pada saat peristiwa itu terjadi dengan mencatat tanggal peristiwa tersebut.

\section{Metode Analisis}

Metode analisis yang digunakan dalam penelitian ini adalah metode event study untuk diproses dan mendiskusikan data yang diperoleh. Langkah-langkah yang dilakukan sebelum menganalisis data yaitu:

1. Mengidentifikasi tanggal peristiwa pengumuman peringkat sukuk. Dalam rangka menyederhanakan diskusi, tanggal dimana pengumuman peringkat sukuk terjadi diidentifikasi sebagai hari nol $(\mathrm{t}=$ $0)$.

2. Menentukan periode peristiwa pengukuran reaksi pasar dari tanggal pengumuman peringkat sukuk terjadi. Periode peristiwa yang digunakan adalah selama 11 (sebelas) hari, yang terdiri dari 5 (lima) hari sebelum peristiwa, 1 (satu) hari pada saat peristiwa, dan 5 (lima) hari setelah peristiwa.

3. Menghitung abnormal return:

a. Menghitung actual return harian dari masing-masing saham perusahaan sampel dalam jangka waktu 11 (sebelas) hari dengan rumus:

$$
\mathrm{R}_{\mathrm{i}, \mathrm{t}}=\left(\mathrm{P}_{\mathrm{i}, \mathrm{t}}-\mathrm{P}_{\mathrm{i}, \mathrm{t}-1}\right): \mathrm{P}_{\mathrm{i}, \mathrm{t}-1}
$$

\section{Keterangan:}

$\mathrm{R}_{\mathrm{i}, \mathrm{t}} \quad=$ actual return sekuritas i pada hari ke-t

$\mathrm{P}_{\mathrm{i}, \mathrm{t}} \quad=$ harga sekuritas i pada hari ke-t

$\mathrm{P}_{\mathrm{i}, \mathrm{t}-1} \quad=$ harga sekuritas i pada hari ke-t-1

b. Menghitung return pasar harian menggunakan market-adjusted model (model disesuaikan pasar) dengan rumus: 


$$
\mathrm{Rm}=\left(\mathrm{IHSG}_{\mathrm{t}}-\mathrm{IHSG}_{\mathrm{t}-1}\right): \mathrm{IHSG}_{\mathrm{t}-1}
$$

Keterangan:

$\mathrm{Rm} \quad=$ Return indeks pasar

$\mathrm{IHSG}_{\mathrm{t}}=$ IHSG pada hari ke-t

$\mathrm{IHSG}_{\mathrm{t}-1}=\mathrm{IHSG}$ pada hari ke-t-1

c. Menghitung return tidak normal atau abnormal return harian setiap sekuritas dengan rumus:

$$
\mathrm{RTN}_{\mathrm{i}, \mathrm{t}}=\mathrm{R}_{\mathrm{i}, \mathrm{t}}-\mathrm{Rm}
$$

Keterangan:

$\mathrm{RTN}_{\mathrm{i}, \mathrm{t}}=$ return tidak normal sekuritas i pada hari ke-t

$\mathrm{R}_{\mathrm{i}, \mathrm{t}} \quad=$ actual return sekuritas i pada hari ke-t

$\mathrm{Rm} \quad=$ Return indeks pasar

d. Menghitung rata-rata return tidak normal (average abnormal return) pada hari ke-t setiap sekuritas dengan rumus:

$$
\operatorname{RRTN}_{\mathrm{t}}=\left(\sum_{\mathrm{i}-1}^{\mathrm{n}} \operatorname{RTN}_{\mathrm{i}, \mathrm{t}}\right): k
$$

Keterangan:

$\mathrm{RRTN}_{\mathrm{t}}=$ rata-rata return tidak normal pada hari ke-t

$\mathrm{RTN}_{\mathrm{i}, \mathrm{t}}=$ return tidak normal sekuritas i pada hari ke-t

$k \quad=$ jumlah seluruh sekuritas yang terpengaruh oleh pengumuman

4. Untuk mengetahui apakah terdapat perbedaan antara rata-rata abnormal return yang diperoleh oleh investor sebelum dan setelah peristiwa pengumuman peringkat sukuk, maka tes yang sesuai untuk penelitian ini adalah paired-sample t-test. Uji beda atau uji-t ( $t$-test) digunakan untuk menguji perbedaan abnormal return dari seluruh saham pada 5 (lima) hari sebelum sampai 5 (lima) hari setelah peristiwa pengumuman peringkat sukuk. Nilai rata-rata abnormal return menunjukkan reaksi pasar. Pengujian dilakukan dengan menggunakan program olah data SPSS.
Dasar pengambilan keputusan dalam penelitian ini melalui pertimbangan sebagai berikut:

a. Jika Sig. (2-taled $)<0,05$ maka $\mathrm{H}_{0}$ ditolak dan $\mathrm{H}_{\mathrm{a}}$ diterima yang artinya terdapat perbedaan abnormal return antara sebelum dan setelah pengumuman peringkat sukuk.

b. Jika sebaliknya Sig. (2-taled) $>0,05$ maka $\mathrm{H}_{0}$ diterima dan $\mathrm{H}_{\mathrm{a}}$ ditolak yang artinya tidak terdapat perbedaan abnormal return antara sebelum dan setelah pengumuman peringkat sukuk.

\section{Hasil dan Pembahasan Deskripsi Objek Penelitian}

Penelitian ini bertujuan untuk melihat dampak dari peristiwa pengumuman peringkat sukuk terhadap reaksi pasar pada perusahaan yang pernah terdaftar di Jakarta Islamic Index (JII) dari tahun 2011-2015 dengan mengamati rata-rata abnormal return 5 (lima) hari sebelum sampai 5 (lima) hari setelah peristiwa. Objek dalam penelitian ini ditentukan menggunakan metode purposive sampling dengan kriteria-kriteria yang telah ditetapkan.

Data yang digunakan dalam penelitian ini adalah pooled/panel data, yaitu data yang diperoleh dalam beberapa periode pengamatan dan memiliki jumlah observasi yang berbeda pada setiap tahun. Berdasarkan data yang diperoleh dari www.finance.yahoo.com dan www.sahamok.com, populasi pada penelitian ini adalah seluruh perusahaan yang pernah terdaftar di Jakarta Islamic Index (JII) dan mengeluarkan sukuk dari tahun 2011-2015. Sesuai dengan kriteria-kriteria yang telah ditetapkan, maka diperoleh sampel sebanyak 5 perusahaan. Dari 5 perusahaan tersebut, terdapat 15 peristiwa pengumuman peringkat sukuk selama periode penelitian yang menjadi amatan.

\section{Hasil Pengujian}

Hasil Uji Paired-Sample T-Test pada Rata-rata Abnormal Return Sebelum dan Sesudah Peristiwa Pengumuman Peringkat Sukuk

Paired Samples Statistics

\begin{tabular}{|ll|r|r|r|r|}
\hline & Mean & N & \multicolumn{1}{c|}{ Std. Deviation } & \multicolumn{1}{c|}{ Std. Error Mean } \\
\hline Pair 1 & AR Sebelum & -.09808 & 15 & .801815 & .207028 \\
& AR Sesudah & -.07531 & 15 & .463011 & .119549 \\
\hline
\end{tabular}


Paired Samples Correlations

\begin{tabular}{|l|r|r|r|}
\hline & N & Correlation & Sig. \\
\hline Pair 1 AR Sebelum \& AR Sesudah & 15 & -.264 & .342 \\
\hline
\end{tabular}

Paired Samples Test

\begin{tabular}{|c|c|c|c|c|c|c|c|c|}
\hline & \multicolumn{5}{|c|}{ Paired Differences } & \multirow[b]{3}{*}{$\mathrm{t}$} & \multirow[b]{3}{*}{$\mathrm{df}$} & \multirow{3}{*}{$\begin{array}{l}\text { Sig. }(2- \\
\text { tailed) }\end{array}$} \\
\hline & \multirow[b]{2}{*}{ Mean } & \multirow{2}{*}{$\begin{array}{c}\text { Std. } \\
\text { Deviation }\end{array}$} & \multirow{2}{*}{$\begin{array}{l}\text { Std. Error } \\
\text { Mean }\end{array}$} & \multicolumn{2}{|c|}{$\begin{array}{l}95 \% \text { Confidence Interval of } \\
\text { the Difference }\end{array}$} & & & \\
\hline & & & & Lower & Upper & & & \\
\hline $\begin{array}{ll}\text { Pair 1 } & \text { AR Sebelum - } \\
& \text { AR Sesudah }\end{array}$ & -.022768 & 1.026214 & .264967 & -.591066 & .545530 & -.086 & 14 & .933 \\
\hline
\end{tabular}

Sumber: Output SPSS (Data Diolah, 2017)

Berdasarkan tabel diatas, dapat dilihat bahwa nilai signifikansi adalah sebesar 0,933 , yang artinya melebihi batas probabilitas yang telah ditentukan yaitu sebesar 0,05. Berdasarkan hasil olah data tersebut maka dapat disimpulkan bahwa pasar tidak bereaksi secara signifikan terhadap peristiwa pengumuman peringkat sukuk. Hasil ini tidak berhasil mendukung hipotesis yang diajukan.

\section{Pembahasan}

Hipotesis yang diuji menggunakan SPSS menunjukkan nilai signifikansi sebesar 0,933 artinya lebih besar dari $\alpha(0,05)$. Hal ini menunjukkan bahwa peristiwa pengumuman peringkat sukuk tidak menimbulkan reaksi pasar yang signifikan. Harga saham selama 5 (lima) hari sebelum sampai 5 (lima) hari setelah peristiwa pengumuman peringkat sukuk terhadap 5 perusahaan yang menjadi sampel penelitian menunjukkan bahwa terdapat perbedaan harga pasar relatif.

Hasil penelitian ini juga menunjukkan adanya perusahaan yang terlihat mengalami kenaikan harga saham walaupun hasil pemeringkatan terhadap sukuk perusahaan tersebut menurun. Hal ini terjadi karena para investor masih meragukan gambaran mengenai prospek perusahaan di masa yang akan datang dan juga dikarenakan sebagian investor masih mempercayai perusahaan walaupun setelah peristiwa pengumuman peringkat sukuk. Hasil penelitian juga menunjukkan adanya perusahaan yang terlihat mengalami penurunan harga saham walaupun hasil pemeringkatan terhadap sukuk perusahaan tersebut meningkat. Penurunan yang terjadi juga tidak telihat signifikan dengan alasan investor mulai kekurangan kepercayaan terhadap perusahaan setelah melihat pengumuman peringkat sukuk.

Secara keseluruhan dari hasil pengujian sampel terhadap rata-rata abnormal return perusahaan sebelum dan setelah peristiwa pengumuman peringkat sukuk diperoleh nilai sebesar 0,933 yang lebih besar dari 0,05 , maka dapat dikatakan bahwa $\mathrm{H}_{0}$ diterima dan Ha ditolak, artinya tidak terdapat perbedaan abnormal return antara sebelum dan setelah terjadinya pengumuman peringkat sukuk. Abnormal return tersebut tidak menunjukkan perbedaan yang signifikan. Hal ini dikarenakan jumlah perusahaan yang mengalami kenaikan maupun penurunan hampir sama, sehingga nilai kenaikan dan penurunannya saling menutupi. Pengujian secara keseluruhan menyatakan tidak terdapat perbedaan yang signifikan terhadap abnormal return relatif. Namun ketika pengujian dilakukan pada saham yang mengalami kenaikan atau penurunan saja, hasilnya menyatakan bahwa terdapat perbedaan yang signifikan antara abnormal return relatif sebelum dan setelah peristiwa pengumuman peringkat sukuk.

Hasil penelitian ini tidak sejalan dengan teori sinyal yang menyatakan bahwa informasi yang baik akan menyebabkan reaksi pasar yang positif, begitu pula dengan informasi yang buruk juga akan menyebabkan reaksi pasar yang negatif. Hasil penelitian ini sejalan dengan penelitian yang pernah dilakukan oleh Nurjanah (2016), Srianingsih dan Khoiruddin (2015), dan Archana dan Jayanna (2015). Penelitian yang mereka lakukan menyatakan bahwa secara umum tidak ditemukannya perbedaan return yang signifikan antara sebelum dan setelah pengumuman peringkat sukuk. Hasil penelitian ini tidak sejalan dengan penelitian yang dilakukan oleh 
Rao dan Sreejith (2013) yang menyimpulkan bahwa pengumuman rating upgrade tidak berpengaruh signifikan terhadap harga saham, sedangkan pengumuman rating downgrade berpengaruh signifikan terhadap harga saham.

Secara teoritis peristiwa pengumuman peringkat sukuk dapat memberikan informasi kepada investor mengenai gambaran perusahaan di masa yang akan datang. Penjelasan sebelumnya menyimpulkan bahwa peristiwa pengumuman peringkat sukuk upgrade seharusnya menimbulkan reaksi pasar yang positif. Begitu pula sebaliknya, peristiwa pengumuman peringkat sukuk downgrade seharusnya menimbulkan reaksi pasar yang negatif. Hal ini tidak sejalan dengan hasil penelitian dikarenakan pada umumnya, ketika seorang investor akan melakukan investasi pada sukuk suatu perusahaan, investor tidak hanya menggunakan peringkat sebagai satu-satunya indikator untuk menilai mutu dari sukuk tersebut. Namun terdapat beberapa faktor lainnya yang tidak dijelaskan dalam penelitian ini yang juga dapat mempengaruhi dasar pengambilan keputusan investor. Beberapa faktor tersebut dapat berasal dari faktor internal perusahaan seperti kinerja keuangan perusahaan, kepemimpinan, prospek perusahaan, dan lain sebagainya. Faktor lainnya juga dapat berasal dari faktor eksternal perusahaan seperti ketidakstabilan ekonomi dan politik di sebuah negara. Faktor-faktor tersebut diyakini dapat mempengaruhi investor untuk melakukan transaksi penjualan atau pembelian saham maupun obligasi pada suatu perusahaan sehingga akan menimbulkan reaksi pasar.

\section{Kesimpulan, Keterbatasan, dan Saran}

Berdasarkan penjelasan-penjelasan yang telah diuraikan sebelumnya, maka penelitian yang bertujuan untuk menganalisis dampak dari peristiwa pengumuman peringkat sukuk terhadap reaksi pasar pada perusahaan yang pernah terdaftar di Jakarta Islamic Index (JII) dengan melihat rata-rata abnormal return 5 (lima) hari sebelum sampai 5 (lima) hari setelah peristiwa, menghasilkan kesimpulan bahwa secara keseluruhan tidak terdapat perbedaan rata-rata abnormal return antara sebelum dan setelah peristiwa pengumuman peringkat sukuk. Hal ini dapat dilihat dari hasil analisis yang menunjukkan nilai signifikansi yaitu sebesar 0,933 dan lebih besar dari 0,05. Hal tersebut dapat terjadi karena tanggapan pasar yang turut dipengaruhi oleh faktor-faktor selain peristiwa pengumuman peringkat sukuk.

Seperti pada penelitian-penelitian lainnya, penelitian ini juga mempunyai beberapa keterbatasan. Keterbatasan-keterbatasan tersebut adalah sebagai berikut.

1. Peristiwa pengumuman peringkat sukuk merupakan peristiwa yang masih jarang terjadi di pasar modal Indonesia apabila dibandingkan dengan peristiwa pengumuman peringkat obligasi, sehingga sampel yang terlalu sedikit menjadi kekurangan dalam melakukan penelitian.

2. Pembahasan atau kajian yang mengangkat tentang topik ini relatif masih sedikit, sehingga kurangnya informasi yang didapat oleh peneliti.

Adapun saran yang ingin diberikan oleh peneliti adalah sebagai berikut.

1. Bagi investor dan calon investor, dalam mengambil keputusan saat akan melakukan investasi sebaiknya memperhatikan kebijakan dan informasi yang dikeluarkan oleh suatu perusahaan. Karena informasi tersebut dapat dijadikan acuan dan bahan pertimbangan sehingga diharapkan keputusan yang akan diambil nantinya menjadi suatu keputusan yang tepat.

2. Bagi perusahaan (emiten) khususnya perusahaanperusahaan yang masuk dalam kelompok Jakarta Islamic Index (JII), hasil penelitian ini memberikan informasi bahwa peristiwa pengumuman peringkat sukuk tidak menjamin pasar akan bereaksi positif ataupun negatif. Oleh karena itu, perusahaan perlu mempertimbangkan faktor-faktor internal dan eksternal lainnya yang juga dapat mempengaruhi reaksi pasar.

3. Bagi peneliti selanjutnya, agar dapat mencoba menggunakan variabel-variabel lain untuk melihat reaksi pasar seperti kondisi keuangan perusahaan maupun aspek-aspek internal dan eksternal lainnya. Dengan demikian, diharapkan hasil penelitian dapat menggambarkan reaksi pasar.

\section{Daftar Pustaka}

Ahmad, Gatot Nazir \& Mohammad Zakaria. 2011. Pengaruh Bond Rating terhadap Imbal Hasil Saham di Bursa Efek Indonesia. Jurnal Riset Manajemen Sains Indonesia (JRMSI). Vol. 2. No. 1. 
Ang, Robbert. 1997. Pasar Modal Indonesia (The Intelligent Guide to Indonesian Capital Market). Jakarta: Mediasoft Indonesia.

Brigham, Eugene F. \& Joel F. Houston. 2006. Dasardasar Manajemen Keuangan. Buku 1. Edisi 10. Jakarta: Salemba Empat.

Darmadji, Tjiptono \& Fakhruddin. 2006. Pasar Modal Indonesia. Jakarta: Salemba Empat.

Jogiyanto. 2003. Teori Portofolio dan Analisis Investasi. Yogyakarta: BPFE.

Jogiyanto. 2010. Studi Peristiwa: Menguji Reaksi Pasar Modal Akibat Suatu Peristiwa. Edisi Pertama. Yogyakarta: BPFE.

Manullang, Timbul Laurence Adolf. 2004. Analisis Efisiensi Pasar Modal Indonesia Menggunakan Pendekatan Multiple Event Sosial \& Politik dan Ekonomi. Disertasi Tidak Dipublikasikan. Jakarta: Program Doktor Ilmu Ekonomi Universitas Persada Indonesia YAI.

Nurjanah, Siti. 2016. Pengaruh Pengumuman Peringkat Obligasi dan Peringkat Sukuk Perusahaan terhadap Abnormal Return di Indonesia. Publikasi Ilmiah.

N., Archana H. \& Dr. S. Jayanna. 2015. Impact of Rating Changes on Stock Prices in India - A Study of Banking Sector. International Multidisciplinary E-Journal. Vol. IV (Aug, 2015). Issue. VIII.

Primadani, Resi. 2013. Reaksi Pasar Saham terhadap Pengumuman Penerbitan Obligasi Syariah di Bursa Efek Indonesia. Jurnal Ilmu Manajemen. Vol. 1. No. 1.

Rahardjo, Sapto. 2003. Panduan Investasi Obligasi. Jakarta: PT. Gramedia Pustaka Utama.

Rao, S. V. D. Nageswara \& Sreejith U. 2013. Impact of Credit Ratings (Upgrade and Downgrade) on Stock Prices in India. Proceedings of 23rd International Business Research Conference. 18-20 November 2013.

Republik Indonesia. Undang-Undang No. 19 Tahun 2008 Tentang Surat Berharga Syariah Negara (SBSN).

Samsul, Mohamad. 2006. Pasar Modal dan Manajemen Portofolio. Jakarta: Erlangga.

Suharyadi \& Purwanto S. K. 2004. Statistika: untuk Ekonomi dan Keuangan Modern. Jakarta: Salemba Empat.
Suryawijaya, Marwan Asri \& Faizal Arief Setiawan. 1998. Reaksi Pasar Modal Indonesia terhadap Peristiwa Politik dalam Negeri (Event Study pada Peristiwa 27 Juli 1996). KELOLA. Vol. VII. No. 18. Hal: 137-153.

Srianingsih \& Moh. Khoiruddin. 2015. Pengaruh Pengumuman Peringkat Sukuk terhadap Reaksi Pasar. Management Analysis Journal 4 (2).

Widoatmodjo, Sawidji. 2012. Cara Cepat Memulai Investasi Saham: Panduan Bagi Pemula. Jakarta: PT Elex Media Komputindo.

http://www.syariahsaham.com/p/daftar-saham-jii.html diakses pada tanggal 12 April 2017 pukul 12.45 WIB.

http://www.ojk.go.id/id/kanal/syariah/data-danstatistik/data-produk-obligasi-

syariah/Default.aspx diakses pada tanggal 12 April 2017 pukul 14.15 WIB.

http://pefindo.com/index.php/pageman/page/allrating.p hp?fullpage $=1 \& \mathrm{id}=\% 5 \mathrm{~B} \% 221 \% 22, \% 225 \% 22$, $\% 227 \% 22 \% 5 \mathrm{D} \& \mathrm{id}=\% 5 \mathrm{~B} 1 \% 2 \mathrm{C} 5 \% 2 \mathrm{C} 7 \% 5 \mathrm{D}$ diakses pada tanggal 27 April 2017 pukul 17.10 WIB. 